\title{
MESSAGE PLATFORM ATRIBUT SIGER LAMPUNG DI DALAM KEBHINEKAAN MULTIKULTUR
}

\author{
Dasrun Hidayat ${ }^{1}$, Engkus Kuswarno ${ }^{2}$, Feliza Zubair ${ }^{2}$, Hanny Hafiar ${ }^{2}$ \\ ${ }^{1}$ Universitas Bina Sarana Informatika \\ ${ }^{2}$ Universitas Padjadjaran
}

\begin{abstract}
ABSTRAK
Penelitian ini berfokus pada pengelolaan keberagaman dan kebinekaan di tengah masyarakat Lampung yang multikultur. Aspek yang dikaji yakni pesan komunikasi dan negosiasi nilai keragaman untuk mencapai kebinekaan yang terdapat pada makna Siger. Peneliti menggunakan studi kasus dengan paradigma konstruktivis. Hasil penelitian menemukan bahwa bentuk Siger merupakan lambang kebesaran gelar yang dimiliki masyarakat adat Saibatin Lampung. Siger dengan tujuh lekukan menggambarkan tentang posisi, peran dan tanggung jawab setiap penerima gelar atau Juluk Adok. Lekukan pertama berukuran paling tinggi, artinya posisi paling depan menggambarkan posisi gelar tertinggi. Lekukan berikutnya dengan ukuran semakin pendek merepresentasikan posisi gelar yang berada di bawah posisi gelar sebelumnya dan seterusnya. Adat Saibatin mempunyai tujuh gelar dengan pembagian dua wilayah Ke-Bandakhan dan Ke-Sebatinan. Ke-Bandakhan terdiri dari gelar Sultan, Pangikhan, Dalom/Sebatin. Ke-Sebatinan meliputi gelar Dalom/Sebatin, Khaja, Khadin, Minak, Kimas, Mas dan Layang/Bunga. Message Platform pada atribut Siger menonjolkan tentang identitas budaya yang menghasilkan integrasi budaya melalui pernikahan antar suku yang harus dikelola oleh setiap penerima gelar. Tanggung jawab untuk mengelola keberagaman adat istiadat di tengah kebinekaan masyarakat multikultur. Reputasi bahwa masyarakat Lampung ramah dan terbuka menjadi salah satu faktor perekat keberagaman menjadi kebinekaan.
\end{abstract}

Kata-kata Kunci: Juluk adok, kebinekaan, message platform, reputasi, siger

\section{MESSAGE PLATFORM OF LAMPUNG SIGER ATTRIBUTES IN MULTICULTURAL DIVERSITY}

\begin{abstract}
This study focuses on the diversity management in a multicultural society such as Lampung. Moreover, this research also studied the message communication and negotiation value of diversity to achieve diversity contained in the meaning of Siger. Using a case study with a constructivist paradigm, the study found that the shape Siger as a symbol of the greatness of titles owned by indigenous peoples Saibatin Lampung. Siger with grooves tujuah describes the position, role and responsibility of each title or Juluk Adok. Highest first indentation size, meaning that the front position describes the position of the highest degree. Indentation next to the size of the shorter means that the position of title under the previous degree position and so on. Indigenous Saibatin have tujuah titles with the division of the two areas Ke-Bandakhan and Ke-Sebatinan. Ke-Bandakhan consists of the title of Sultan, Pangikhan, Dalom/Sebatin. Ke-Sebatinan include titles Dalom/ Sebatin, Khaja, Khadin, Minak, Kimas, Mas and Layang/Bunga. Message Platform that exist on the attributes of Siger highlight of cultural identity that generates cultural integration through inter-tribal marriages that must be managed by each degree recipients. Responsibility for managing the diversity of customs in the middle of the diversity of multicultural society. Reputation that Lampung people are friendly and open to be one factor adhesive diversity into diversity.
\end{abstract}

Keywords: Juluk adok, diversity, message platform, reputation, siger

Korespondensi: Dr. Dasrun Hidayat, M.I.Kom. Fakultas Ilmu Komunikasi Universitas Bina Sarana Informatika. Jalan Sekolah Internasional no.1-6 Antapani, Cicaheum, Kiaracondong, Kota Bandung, Jawa Barat 40291 e-mail: dasrun.duh@bsi.ac.id. 


\section{PENDAHULUAN}

Lampung merupakan provinsi yang terletak di ujung selatan Pulau Sumatera. Lampung memiliki letak geografis yang strategis, sehingga banyak pendatang berkunjung bahkan menetap di Lampung dan menjadi bagian dari masyarakat penghasil kain tapis ini. Pesona geografis yang kaya akan sumber daya alam seperti flora, fauna, hasil pertanian, tempat wisata hingga seni, dan budayanya menjadikan Lampung sebagai provinsi yang multikultur. Pesona tersebut telah mengundang banyak orang luar untuk menetap menjadi warga Lampung. Saat ini komposisi suku di Lampung terdiri dari $25 \%$ suku Lampung, dan 75\% suku dari luar seperti Jawa Barat, Jawa Tengah, Sumatera di luar Lampung dan Bali (Sujadi, 2012: 2). Data kependudukan Lampung tersebut meyakinkan bahwa Lampung sejak awal sudah terbiasa hidup dengan nuansa keragaman. Ragam suku di Lampung tidak melahirkan jarak yang jauh antarsuku. Lampung dengan multikulturnya secara dini sudah mempersiapkan diri untuk menerima kehadiran masyarakat yang multikultur. Parekh dalam Hidayat menjelaskan bahwa istilah masyarakat multikultural dan multikulturalisme pada umumnya digunakan untuk merujuk pada suatu masyarakat yang menunjukkan tiga keanekaragaman yaitu subkultural, keanekaragaman perspektif, dan keanekaragaman komunal (Hidayat, 2014: 123).

Kesiapan Lampung menjadi wilayah dengan masyarakat multikultur, dapat ditemukan pada salah satu atribut khas masyarakat Lampung yaitu Siger. Terdapat pesan sekaligus nasihat yang ingin disampaikan oleh para leluhur melalui media komunikasi Siger. Pesan utama atau message platform di dalam atribut Siger bahwa siapa pun yang menetap dan mengikrarkan dirinya sebagai Ulun Lampung sudah seharusnya mendapatkan peran dan tanggung jawab untuk memajukan Lampung. Hal itu terangkum di dalam salah satu falsafah hidup masyarakat Lampung yaitu Juluk Adok atau pemberian gelar. Juluk Adok menggambarkan tentang kepribadian setiap masyarakat Lampung harus sesuai dengan gelar adat yang disandangnya (Sujadi, 2012: 75).

Atribut Siger memiliki tujuh lekukan dari depan ke belakang yang menggambarkan tentang tradisi Juluk Adok atau gelar yang merupakan bagian dari lima falsafah hidup Ulun Lampung.
Setiap lekukan menggambarkan posisi, peran, dan tanggung jawab penyandang (penyimbang) gelar. Ukuran setiap lekukan berbedabeda, mulai dari lekukan pertama berbentuk paling tinggi, artinya posisi paling depan menggambarkan posisi gelar tertinggi. Lekukan berikutnya dengan ukuran semakin pendek artinya posisi gelar yang berada di bawah posisi gelar sebelumnya dan seterusnya. Adat Saibatin mempunyai tujuh gelar dengan pembagian dua wilayah Ke-Bandakhan dan Ke-Sebatinan. KeBandakhan terdiri dari gelar Sultan, Pangikhan, Dalom/Sebatin, Khaja, Khadin, Minak dan Kimas. Ke-Sebatinan meliputi gelar Dalom/ Sebatin, Khaja, Khadin, Minak, Kimas, Mas dan Layang/Bunga. Siger juga merepresentasikan bahwa masyarakat adat Saibatin mengenal tiga kelompok gelar yaitu kelompok gelar sebagai pimpinan adat, kelompok gelar sebagai Jakhu Suku, dan kelompok gelar sebagai khekhayahan. Message Platform yang ada pada atribut Siger menonjolkan tentang peran dan tanggung jawab. Peran sebagai perangkat adat dan tanggung untuk mengelola adat istiadat di tengah kebinekaan masyarakat multikultur.

Keragaman budaya tentu saja akan menghasilkan identitas budaya yang juga beragam. Hal ini akan menjadi kompleks ketika kita tidak dapat menemukan dan menjelaskan identitas. Martin dan Thomas menyatakan bahwa identitas berhubungan dengan pernyataan identitas dan status manakala berinteraksi dengan orang berbeda budaya. Steward menjelaskan bahwa identitas adalah sebuah proses pengungkapan status secara verbal dan nonverbal kepada orang lain (Aryanti, 2014: 94). Suparlan menilai bahwa isu tentang etnis merupakan realitas yang masih tampak dalam kehidupan sehari-hari dalam masyarakat Indonesia yang majemuk (Heryadi, Silvana, 2013: 93). Mereka dilahirkan, dididik, dan dibesarkan dalam suasana askriptif primordial etnistitas. Sebagai akibatnya perbedaan antara "siapa saya" dengan "siapa anda" atau "siapa" kami" dengan "siapa mereka" terlihat dengan jelas batasannya. Dalam situasi ini dikuatirkan masyarakat dengan ragam etnis tersebut tidak dapat melawan sisi gelap dari identitas budaya seperti stereotip, etnosentrisme, rasisme, prasangka, dan lainnya. Sisi gelap perbedaan budaya tersebut merupakan faktor penghambat komunikasi antarbudaya sekaligus faktor pemicu terjadinya konflik di tengah masyarakat 
multikultur.

Identitas budaya kadangkala terbentuk karena bawaan atau warisan dari orangtua, atau dibentuk berdasarkan pengakuan seseorang. Identitas yang didasarkan pengakuan terjadi karena pengaruh lingkungan. Identitas pribadi seseorang merupakan jawaban atas pertanyaan orang lain ketika menanyakan status seseorang. Identitas dalam masyarakat multikultural seperti di Lampung memang tidak dapat dipungkiri apabila terjadinya integrasi budaya. Hal ini didorong oleh jumlah migrasi yang lebih banyak dibandingkan jumlah penduduk asli. Salah satu bentuk dari integrasi budaya yakni pernikahan antarbudaya dan pengaruh globalisasi. Hal itu dipengaruhi pula olah muatan media sehingga juga berkontribusi terhadap integrasi budaya (Samovar, 2010: 201).

Integrasi budaya di Lampung tidak dapat dihindari. Pernikahan antarsuku pribumi Lampung dengan suku pendatang sudah menjadi realitas sosial istimewa. Akan tetapi situasi ini akan menjadi rumit tatkala pernikahan antarbudaya tersebut membuat kabur budaya anak-anaknya. Hal ini yang menjadi kelemahan dari integrasi budaya. Identitas seseorang terdiri dari berbagai identitas yang saling berhubungan. Suatu identitas menjadi penting tergantung dari situasi yang ada. Di sisi lain, integrasi budaya dapat membantu proses pengelolaan keragaman budaya di tengah masyarakat multikultur. Misalnya, integrasi budaya melalui pernikahan antarbudaya, secara langsung dapat menyatukan dua budaya sehingga terjadi penerimaan antarbudaya. Terjadinya integrasi budaya dapat membantu terwujudnya kebinekaan di dalam masyarakat majemuk seperti Lampung. Aryanti menjelaskan dalam hasil penelitiannya tentang interaksi remaja transmigran etnis Jawa di Lampung bahwa identitas remaja ketika di lingkungan sekolah tidak berkontribusi terhadap pengembangan identitas etnik (Aryanti, 2014: 103). Artinya bahwa identitas tidak dibangun secara permanen. Hal ini dapat pula disebabkan oleh pernikahan antarbudaya sehingga anak merasa bingung ketika ditanya tentang identitas budayanya. Samovar menjelaskan bahwa pengembangan identitas ketika belajar di kelas, maka identitas utamanya adalah sebagai seorang pelajar. Akan tetapi ketika tiba di tempat pekerjaan, identitas sebagai karyawan. Dalam gambaran situasi tersebut apapun identitas yang ditunjukkan tetap saja dipengaruhi oleh identitas budaya (Samovar, 2010: 196). Identitas budaya merupakan identitas permanen yang sifatnya diwariskan. Sebesar apapun usaha untuk menutupi identitas etnik, tetap saja ada bagian tertentu yang mempertegas secara tidak langsung siapa identitas etnik seseorang.

Identitas dalam kajian ini adalah pemberian gelar atau Juluk Adok yang diberikan kepada anggota masyarakat Lampung yang telah menikah. Gelar bertujuan untuk menunjukkan identitas setiap anggota masyarakat adat Lampung. Gelar di dalam masyarakat adat Saibatin Lampung diberikan kepada siapapun dengan catatan telah menikah dengan suku Lampung. Gelar juga memicu terjadinya perkawinan antarbudaya sehingga mendorong lahirnya budaya baru dan identitas campuran. Seiring dengan penyematan gelar seseorang dipastikan mendapat identitas diri baru serta peran dan tanggung jawab baru sebagai perangkat adat. Peran sebagai perangkat adat memiliki kewajiban untuk mengelola adat istiadat Lampung. Salah satu tanggung jawab yakni menjaga reputasi Lampung sebagai provinsi multikultur dengan kebinekaannya.

Reputasi merupakan bagian dari ilmu Public Relations. Grunig dalam Alison menyebutkan beberapa aktivitas utama Public Relations terdiri dari publik, media, hubungan, program, strategi, output, outcome, citra, dan reputasi (Alison, 2004: 115). Reputasi berarti sebagai rekam jejak seseorang, kelompok dan instansi. Reputasi yang baik tatkala memiliki beberapa kriteria. Hal ini diungkapkan Fombrun dalam Ardianto bahwa reputasi dibentuk karena adanya rasa tanggung jawab, kredibilitas, realibilitas, dan kepercayaan. Satu dengan lainnya saling berkaitan erat (Fombrun dalam Ardianto, 2013: 69). Pada konteks kajian ini peneliti menggunakan istilah reputasi sebagai bagian dari kajian PR Budaya atau aktivitas PR berbasis budaya. Reputasi yang direpresentasikan melalui atribut Siger yang mengandung nilai-nilai kearifan lokal. Nilai yang menegaskan bahwa setiap individu yang mengaku sebagai warga Lampung berkewajiban untuk menjaga adat istiadat setempat. Tanggung jawab terhadap pelestarian budaya tidak semata kewajiban suku Lampung dan pemerintah setempat melainkan tanggung jawab bersama.

$$
\text { Masyarakat Lampung senantiasa }
$$
menjaga reputasi melalui implementasi nilainilai yang terdapat pada atribut Siger ke dalam 
kehidupan sehari-hari. Reputasi yang hingga saat ini dipertahankan adalah Ulun Lampung sangat menjunjung tinggi sikap ramah dan terbuka atau Nemui-Nyimah (Hidayat, 2014: 93). Artinya Lampung sebagai wilayah yang terbuka untuk para pendatang atau nonpribumi. Ulun Lampung memperlihatkan keramahan dan keterbukaan terhadap suku lain yang menetap di Lampung. Kondisi seperti ini sangat diharapkan dalam upaya menumbuhkan rasa saling percaya. Kepercayaan dibangun karena adanya kompetensi komunikasi antarwarga seperti kompetensi mengenali budaya diri sendiri, dan budaya orang lain. Adanya kepercayaan sudah barang tentu sangat membantu dalam mempertahankan reputasi Lampung sebagai wilayah multikultur, seperti yang digambarkan pada pesan komunikasi di dalam lekukanlekukan atribut Siger.

Pesan utama yang akan disampaikan dalam sebuah program disebut message platform. Hal ini dilakukan untuk membantu dalam merumuskan tujuan dan target program. Smith dalam Prayudi menetapkan message platform diawali dari tahapan analisis situasi (Prayudi, 2012: 157). Langkah ini diambil untuk mendefinisikan masalah dan memahami penyebab dari masalah tersebut. Tench menekankan bahwa message platform bagian dari strategi aksi mempersiapkan konten yang akan disampaikan pada tiap kegiatan (Tench, Yeomans, 2006: 195). Keterkaitan message platform dengan penelitian ini yaitu keputusan pimpinan adat menempatkan nilai-nilai budaya berupa falsafah hidup masyarakat Lampung ke dalam atribut Siger. Bentuk Siger dengan lekukan berjumlah tujuh menggambarkan tentang salah satu falsafah hidup yaitu identitas diri berupa gelar. Siger sebagai media komunikasi untuk menyampaikan nasehat dari para leluhur tentang identitas diri masyarakat Lampung yang senantiasa berperilaku terpuji sesuai dengan gelar yang disandangnya.

Pesan utama di dalam Siger dirancang seakan sudah dapat diprediksi bahwa Lampung akan ditempati oleh penduduk yang berasal dari berbagai suku. Ketepatan dalam membuat message platform Siger tentu saja bukan kebetulan, akan tetapi melaui pertimbangan dengan memperhatikan faktor internal. Secara internal, Lampung memiliki letak geografis yang strategis sementara sumber daya manusianya masih kurang sehingga membutuhkan orang yang dapat memajukan Lampung.

Realitas tentang upaya masyarakat Lampung menjaga kebinekaan di tengah masyarakat multikultur menjadi fokus sekaligus alasan penelitian ini. Hal itu direpresentasikan di dalam bentuk Siger yang mengandung pesan komunikasi sebagai upaya pengelolaan keberagaman budaya di Lampung. Diharapkan melalui tulisan ini dapat memberikan kontribusi terhadap kajian Public Relations berbasis budaya atau PR Budaya dengan pendekatan nilai kearifan lokal. Hasil penelitian juga dapat memberikan kontribusi terkait gambaran pengelolaan keragaman budaya di Indonesia khususnya pengelolaan keragaman budaya di Lampung.

\section{METODE PENELITIAN}

Penelitian ini menggunakan studi kasus dengan paradigma konstruktivis. Studi kasus mencoba untuk menggali keunikan dari suatu kasus atau multikasus secara holistik dan komprehensif. Pengelolaan keberagaman di Lampung yang digambarkan pada atribut Siger memiliki keunikan tersendiri sehingga manarik untuk ditelaah. Keunikan itu terletak pada nilainilai yang terkandung pada setiap lekukan, bentuk, dan hiasan pada siger. Nilai sebagai nasihat bagi setiap generasi untuk menjalankan peran dan tanggung jawabnya. Peran diberikan kepada siapapun, tidak melihat suku dan asal usul, tetapi peran untuk setiap individu yang menyatakan dirinya menetap di Lampung. Peran dan tanggung jawab tersebut direpresentasikan ke dalam tradisi Juluk Adok atau gelar yang terdapat pada setiap lekukan siger. Creswell menjelaskan bahwa fokus kajian studi kasus untuk mengembangkan deskripsi dan analisis mendalam tentang kasus atau beragam kasus. Pada penelitian khusus pada satu kasus yakni tentang pengelolaan kebhinekaan di tengah situasi multikultur (Creswell, 2014: 145).

Studi kasus sebagai metode penelitian diharapkan dapat menyediakan pemahaman secara mendalam tentang hasil penelitian. Untuk itu, peneliti menggunakan teknik pengumpulan data melalui wawancara terstruktur dan observasi. Penelitian ini dilaksanakan di dua desa di Kabupaten Tanggamus Provinsi Lampung. Sumber data melibatkan beberapa informan yang ditentukan secara purposive sampling. Kriteria informan adalah warga 
Lampung, budayawan, dan tokoh Lampung yang memahami tentang sejarah Lampung. Data dikumpulkan melalui teknik wawancara, observasi, dan melakuan focus group discussion.

\section{HASIL DAN PEMBAHASAN}

Lampung memiliki komoditi unggulan seperti tebu, karet, kopi, dan kakao. Di bidang pertanian dan perekebunan Lampung juga unggul dalam menghasilkan cengkeh dan kelapa sawit. Sedangkan dari sisi pertambangan, Lampung juga tercatat sebagai penghasil emas, mangan, bijih besi, pasir besi, dan panas bumi. Selain itu Lampug juga memiliki pesona alam dan budaya yang indah. Pesona alam seperti wisata Way Kambas, Pantai Teluk Betung, Air Terjun Curup Indah Klawas, Pulau Legundi, Pulau Sebuku, Pulau Sebesi, Pulau Ketagian, Putus, Tabuan, Pulau Poahwang, dan kawasan wisata Land Mark Menara Siger. Dari sisi budaya Lampung memiliki ragam seni tari dan musik serta adat istiadat warisan leluhur. Tarian daerah Lampung seperti tari Sembah, Melinting, dan tari Bedana. Untuk adat istiadat masyarakat Lampung masih sangat menjunjung tinggi nilainilai lokal yang terdapat pada falsafah hidup di antara tradisi pemberian gelar atau Juluk Adok. Lampung memiliki tradisi penyematan gelar untuk setiap anggota adatnya. Gelar sebagai bentuk penghargaan, penghormatan, dan kasih sayang leluhur. Gelar bertujuan untuk mengikat setiap anggota adat melalui peran dan tangggung jawab yang harus dilaksanakan. Nilai-nilai falsafah hidup Ulun Lampung salah satunya Juluk Adok yang digambarkan pada atribut Siger.

Siger merupakan salah satu wujud budaya berupa artefak. Siger sebagai atribut yang dikenakan pada pengantin perempuan beradat Saibatin maupun beradat Pepadun Lampung. Tidak semua orang mengetahui bahwa Siger memiliki filosofi yang tinggi. Orang awam menganggap bahwa Siger hanya benda yang terbuat dari tembaga berwarna kuningan yang diperuntukkan bagi para pengantin perempuan. Orang lain juga beranggapan bahwa Siger hanya menara yang dijadikan sebagai tempat wisata Land Mark Menara yang terletak di perbatasan penyeberangan Bakauheni-Merak. Dari kejauhan setiap orang dapat menyaksikan keindahan menara Siger yang menjulang di atas tanah Lampung. Padahal Siger memiliki arti lebih dari sekedar tempat wisata atau menara yang dibuat dengan megah. Siger menggambarkan tentang falsafah hidup Ulun Lampung atau orang Lampung. Bahkan Lampung juga dikenal dengan sebutan Tanoh Siger atau tanah siger.

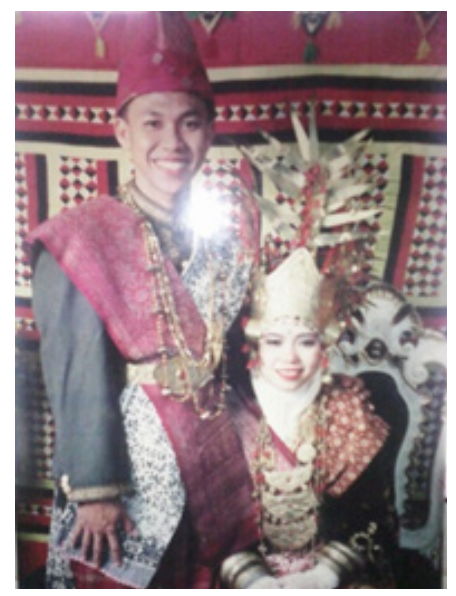

Sumber: Hasil Penelitian 2015-2016

\section{Gambar 1 Siger Saibatin: Atribut Kepala Pada Pengantin Perempuan}

Siger berbentuk melengkung ke belakang. Setiap lengkungan terdapat tujuh lekukan yang berukuran berbeda. Lekukan merepresentasikan tentang perbedaan posisi atau jenis gelar. Lekukan pertama berada paling depan dengan posisi lebih tinggi dibandingkan dengan enam lekukan lainnya. Artinya bahwa terdapat tujuh tingkatan gelar di dalam masyarakat adat Saibatin Lampung. Masing-masing gelar meliputi gelar untuk perangkat adat yang berada di wilayah $\mathrm{Ke}$-Bandakhan dan wilayah Ke-Sebatinan. Ke-Bandakhan terdiri dari gelar tertinggi yaitu Sultan, Pangikhan, Dalom/ Sebatin. Untuk gelar di wilayah Ke-Sebatinan dipimpin oleh orang yang bergelar Dalom/ Sebatin, Khaja, Khadin, Minak, Kimas, Mas, dan Layang/Bunga (wawancara informan Adi Penyantun/Rosmaini 11 Mei 2016).

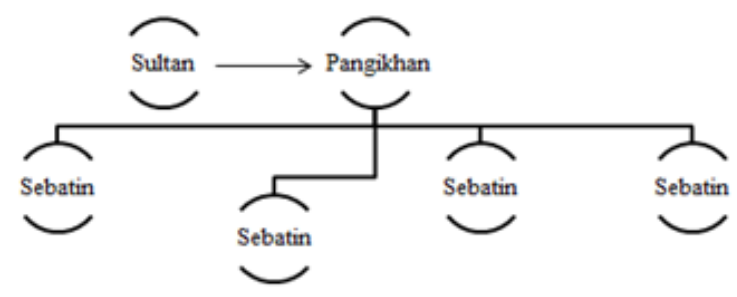

Sumber: Hasil Penelitian 2015-2016

Gambar 2. Wilayah Ke-Bandakhan 
Ke-Bandakhan merupakan wilayah terbesar dan pusat tertinggi pengelolaan adat istiadat. $\mathrm{Ke}$-Bandakhan membawahi beberapa $\mathrm{Ke}$ Sebatinan. Ke-Bandakhan dapat pula diartikan sebagai rumah besar tempat berkumpulnya para petinggi adat Saibatin. Wilayah Ke-Sebatinan termasuk ke dalam Ke-Bandakhan Talangpadang Kabupaten Tanggamus. Perangkat adat yang menduduki posisi di Ke-Bandakhan adalah para perangkat adat yang berasal dari kelompok gelar sebagai pimpinan adat dan Jakhu Suku.

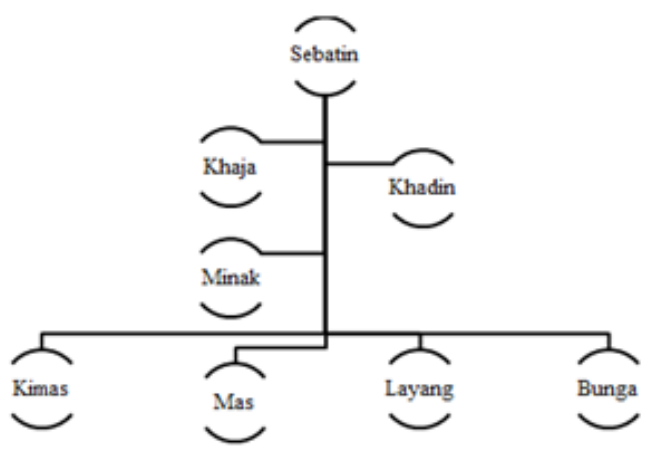

Sumber: Hasil Penelitian 2015-2016

\section{Gambar 3. Wilayah Ke-Sebatinan}

Wilayah Ke-Sebatinan merupakan pengelola budaya yang terdapat disetiap desa. Ke-Sebatinan menempatkan beberapa perangkat gelar terdiri dari Dalom, Batin, Khaja, Khadin, Minak, Kimas, Mas, dan Layang. Ke-Sebatinan wilayahnya lebih kecil dibandingkan Ke-Bandakhan. Orang-orang yang terlibat dalam pengelolaan adat istiadat di Ke-Sebatinan memiliki tanggung jawab terhadap masing-masing desa sebagai bagian dari wilayahnya. Sedangkan Ke-Bandakahan mencakup semua wilayah Ke-Sebatinan yang berada di bawahnya.

Berdasarkan hasil observasi, ada pula yang berpendapat bahwa lekukan Siger berjumlah delapan lekukan. Jumlah lekukan dengan menambahkan gelar Mas untuk wilayah $\mathrm{Ke}$ Bandakhan, dan Bunga untuk Ke-Sebatinan. Perbedaan penafsiran jumlah lekukan tidak menjadi perdebatan. Mereka meyakini bahwa berapapun jumlahnya lekukan pada Siger diyakini sebagai media internal masyarakat Saibatin dalam menyampaikan pesan-pesan budaya. Salah satu pesan budaya tentang tradisi pemberian gelar atau Juluk Adok. Tradisi tersebut tersirat di dalam setiap lekukan Siger. Pesan budaya di dalam atribut siger juga menjadi bagian dari media kampanye untuk membranding tentang kebesaran budaya Lampung.

Siger adat Saibatin selain terdapat tujuh lekukan juga terdapat lima bunga penghias di samping lekukan Siger. Bunga diambil dari tumbuhan Sekala ditempatkan di atas lima lekukan Siger. Sedangkan Siger adat Pepadun mengambil gambar kelopak buah Sekala. Bunga hias tersebut melambangkan falsafah hidup ulun Lampung atau orang Lampung yaitu Pi'il Pusenggikhi atau upaya kontrol diri, Sakai Sambayan atau tolong menolong, Nengah Nyampokh atau pandai bergaul, Nemui Nyimah atau ramah dan terbuka serta Juluk Adok atau gelar, artinya paham dengan kedudukan sehingga diharapkan berperilaku sesuai dengan gelar yang diterimanya.

Bentuk Siger adat Pepadun berbeda dengan siger adat Saibatin. Jika Siger adat Sebatin bentuk lekukan ke belakang dengan jumlah tujuh lekukan, maka adat Pepadun bentuk lekukan ke samping dengan sembilan lekukan. Sembilan lekukan merepresentasikan jumlah marga meliputi marga Unyi, Unyai, Subing Nuban, Anak Tuha, Selagai, Beliyuk, Kunang, dan Nyerupo. Sembilan marga tersebut bergabung menjadi Abung Siwo Megou (wawancara informan Adi Penyantun/Rosmaini 11 Mei 2016).

Provinsi Lampung adalah provinsi yang sejak lama dipersiapkan oleh Pemerintahan Soeharto ketika itu sebagai daerah transmigrasi. Menempatkan pilihan Lampung sebagai wilayah transmigrasi karena di Lampung masih terdapat banyak lahan kosong produktif. Selain itu, secara geografis Lampung juga sangat strategis menghubungkan antara Pulau Sumatera dengan Jawa. Nawacita Presiden Soeharto membuahkan hasil karena hingga saat ini tercatat persentase jumlah penduduk di Lampung lebih banyak nonpribumi dibandingkan pribumi. Dari total penduduk kurang lebih 7.608.405 jiwa sebanyak $75 \%$ adalah nonpribumi dan sisanya 25\% pribumi (Sujadi, 2013: 2). Kondisi ini di satu sisi bukti sebagai keberhasilan pemerataan jumlah penduduk di Indonesia dan keberhasilan dalam pengelolaan keragaman budaya. Di sisi lain menunjukkan bahwa masyarakat Lampung sangat membuka diri untuk siapa saja yang ingin menetap dan menjadi bagian dari warga Lampung.

Di Lampung sukune lamon, wat jawa ne, 
sundane. Nah hinji sebagai bukti bahwa masyarakat Lampung dapok nekhima sapa gaoh si haga netop di Lampung. Sikam terbuka injuk hane falsafah hidup kham Nemui-Nyimah khetine ramah khek terbuka. Suku di Lampung sangat banyak, ada suku Jawa, suku Sunda. Ini sebagai bukti bahwa masyarakat Lampung dapat menerima siapa saja yang ingin tinggal di Lampung. Kami terbuka seperti yang ada dalam falsafah hidup kami Nemui Nyimah, artinya ramah dan terbuka (wawancara informan Adi Penyantun/Rosmaini 11 Mei 2016).

Falsafah hidup Ulun Lampung terdiri diri dari Nemui-Nyimah, Sakai-Sambayan, NengahNyampokh, Juluk-Adok, dan Piil-Pusanggikhi (Hidayat, 2014: 93). Nemui-Nyimah aritnya ramah dan terbuka, Sakai-Sambayan atau gotong royong, Nengah-Nyampokh atau pandai bergaul, Juluk-Adok artinya bersikap sesuai dengan kepribadian dan gelar yang disandangnya. Piil-Pusanggikhi atau jati diri dan harga diri. Satu dari falsafah yakni JulukAdok diinternalisasikan melalui atribut siger. Bentuk Siger dengan tujuh lekukan ke belakang menjadi simbol tentang falsafah hidup Juluk Adok. Falsafah yang mengandung nilai bahwa setiap warga Lampung sudah semestinya berperilaku sesuai dengan gelar yang disandangnya. Artinya bahwa pemberian gelar mengandung tujuan bahwa tidak dibenarkan melakukan tindakan yang dapat merugikan orang lain. Misalnya, seseorang yang bergelar Khadin Darmawan, maka seyogyanya dalam kesehariannya perilaku mencerminkan sebagai pribadi yang suka menolong, tidak sungkan dalam memberikan bantuan kepada siapapun. Sifat darmawan berlaku kepada siapapun, tidak membeda-bedakan asal dan suku. Begitu pula dengan falsafah hidup lainnya. Akan tetapi Juluk Adok yang menjadi telaah penelitian ini memiliki porsi tersendiri karena keberadaannya digambarkan pada bentuk dan philosofi Siger. Selama ini masyarakat hanya mengetahui Siger sebagai atribut pernikahan yang dikenakan oleh mempelai perempuan. Siger sebatas land mark Menara Siger dan Siger hanya sekedar simbol Lampung. Akan tetapi kajian ini membuktikan bahwa keberadaan Siger tidak sesederhana itu. Kehadiran Siger memiliki latar belakang yang kuat dengan cita-cita para leluhur dan pemimpin bangsa. Nilai-nilai yang terdapat pada Siger diharapkan dapat membantu dalam mengelola keragaman budaya di Lampung.

Falsafah hidup Juluk Adok yang terdapat pada atribut Siger seperti telah menjadi isyarat istimewa bahwa Lampung akan menjadi wilayah yang ditempati oleh beragam suku. Isyarat tersebut menjadi nyata ketika jumlah suku asli Lampung yang tidak sebanding dengan jumlah suku-suku para pendatang. Kondisi ini tentu saja melahirkan nuansa baru di Lampung. Nuansa keberagaman budaya di tengah suku Lampung yang minoritas. Situasi yang tidak berarti tanpa meninggalkan persoalan, akan tetapi melahirkan gesekan seperti kesenjangan. Hal ini terbukti ketika terjadi konflik di beberapa wilayah di Lampung. Salah satu faktor pemicu konflik yakni adanya oknum yang dengan sengaja memanfaatkan isu identitas budaya. Keragaman suku sejatinya memang melahirkan banyak identitas budaya. Ragam identitas yang dapat menggambarkan khasanah budaya. Ragam identitas tidak dijadikan sebagai pemicu terbentuknya sisi gelap budaya. Salah satu sisi gelap budaya adalah kelompok menganggap dirinya atau kelompoknya lebih baik, dan orang lain tidak lebih baik. Tindakan yang mengaku kelompoknya lebih baik merupakan tindakan etnosntrieme (Samovar, 2010: 214). Salah satu tindakan yang merupakan sisi gelap masyarakat multikultur. Aspek lain yang harus dihindari dan diwaspadai dalam masyarakat multikultur yakni prasangka, rasisme, dan stereotip.

Keragaman suku di Lampung melahirkan masyarakat yang majemuk, masyarakat multikultur membutuhkan upaya pengelolaan sehingga kemajemukan tersebut dapat melahirkan kebinekaan budaya. Berebeda-beda budaya, adat istiadat tetapi tetap memiliki rasa kebersamaan, rasa sepenanggungan bahwa kita adalah satu, satu tubuh sebagai bangsa Indonesia, dan satu tubuh sebagai warga Lampung. Pengelolaan keragaman masyarakat multikulutr di Lampung sangat disadari oleh pemerintah daerah setempat sehingga salah satu kebijakan mereka yakni membuat tagline atau jargon Lampung berbunyi "Sai Bumi Khua Jukhai". Tagline ini artinya bahwa di dalam tanah Lampung terdiri dari dua penduduk yaitu penduduk pribumi dan nonpribumi. Keduanya diharapkan dapat hidup berdampingan, saling menghormati, saling membantu satu dengan lainnya. Nilai yang terkandung dalam philosofi 
tagline Lampung bertujuan untuk mengingatkan setiap individu yang merasa tinggal di Lampung, lahir besar, dan bekerja di Lampung adalah sama sebagai warga Lampung. Memiliki hak, kedudukan, dan kewajiban yang sama pula dengan suku Lampung pribumi. Penduduk yang berasal dari luar suku Lampung juga mempunyai tanggung jawab memajukan, dan membesarkan Lampung sebagai provinsi yang senantiasa berusaha mengelola keberagaman menuju kebinekaan di Lampung.

Kebinekaan suku di Lampung tentu melahirkan identitas. Akan tetapi identitas tersebut dimaknai secara arif sehingga tidak menimbulkan penolakan atau resistensi dari dari identitas lainnya. Identitas sulit untuk didefinisikan karena identitas merupakan sesuatu yang abstrak, akan tetapi identitas merupakan aspek yang berperan penting dalam interaksi antarbudaya. Identitas terjadi karena adanya globalisasi, pernikahan antarbudaya, dan pola imigrasi menambah kerumitan identitas budaya.

Pentingnya identitas budaya sebagai wujud kebanggaan pribadi terhadap asal-usul yang tidak mungkin dihilangkan. Identitas melekat sehingga identitas akan selalu menyertai perilaku seseorang. Identitas pula yang dapat melahirkan konsep diri seseorang. Membangun identitas karena adanya faktor penilaian terhadap budaya tertentu. Identitas budaya dapat dibangun berdasarkan identitas ras, etnik, gender, nasional, regional, organisasi, dan identitas pribadi (Samovar, 2010: 184). Identitas dapat dipilih artinya setiap individu seyogyanya dapat menempatkan identitasnnya secara bijaksana. Kapan seseorang memperlihatkan identitas pribadinya, dan kapan menunjukkan dirinya beridentitas ras, gender, dan lainnya. Tentu tidak tepat apabila sebuah organisasi masing-masing anggotanya mendahulukan identitas pribadi dan identitas rasnya. Ketika hal ini yang terjadi maka akan menyulut terjadinya konflik. Penempatan identitas budaya yang tidak tepat merupakan faktor utama penghambat komunikasi antarbudaya. Sisi gelap dari komunikasi berbeda budaya adalah identitas budaya. Akan tetapi, identitas budaya akan menjadi aset budaya ketika pelaku komunikasi berbeda budaya dapat menempatkan identitasnya sesuai dengan porsi dan fungsinya.

Keragaman suku di Lampung tidak menjadikan bahwa Lampung sebagai wilayah rawan konflik. Justru Lampung menjadi magnet untuk di kunjungi. Lampung dipilih sebagai tempat tinggal karena dinilai situasinya sangat mendukung. Selain kekayaan alam yang tersedia juga karakteristik masyarakatnya yang siap menerima, terbuka, dan ramah terhadap para pendatang. Sikap keterbukaan suku Lampung terhadap suku pendatang juga dipertegas dalam salah satu falsafah hidup Ulun Lampung. Sujadi menyebutkan Ulun Lampung memiliki sifat Nemui-Nyimah artinya ramah dan terbuka, suku yang suka saling bersilaturahim dengan siapapun tanpa melihat asal-usulnya (Hidayat, 2014: 91). Nilai pada falsafah ini yang kemudian diimplementasikan pada akativitas komunikasi mereka dengan suku pendatang.

Nilai lain yang diyakini sebagai pesan komunikasi dalam membangun integrasi budaya menuju kebinekaan yakni Juluk Adok. Ini merupakan falsafah kedua setelah Nemui Nyimah. Juluk Adok artinya setiap individu atau suku Lampung akan mendapatkan gelar. Gelar sebagai penghargaan, doa, dan harapan bahwa anak-cucu mewarisi kepribadian sesuai dengan gelar yang diterimanya. Gelar salah satunya direpresentasikan pada atribut Siger. Atribut yang biasa digunakan sebagai asesoris kepala pada pengantin perempuan. Siger juga dijadikan sebagai ikon wisata Lampung. Sujadi menjelaskan bahwa Siger saat ini sudah menjadi land mark wisata provinsi Lampung. Menara Siger yang berada di perbatasan penyebrangan Bakauheni-Merak, saat ini sudah menjadi salah satu destinasi wisata di tanah penghasil kerajinan tapis. (Sujadi, 2012: 3).

Aribut Siger juga melambangkan tentang kelompok atau pembagian gelar. Setiap lekukan Siger mengandung nilai tentang sifat dan karakter yang luhur, yakni Ulun Lampung terbuka dan menerima siapa pun yang ingin menetap di Lampung. Bahkan mereka diberikan hak yang sama baik di bidang adat istiadat maupun kesempatan kerja. Keterbukaan Ulun Lampung dibuktikan ketika diperbolehkannya secara adat pernikahan antarbudaya. Kondisi ini mendorong terjadinya proses integrasi budaya. Proses penggabungan budaya karena dilatarbelakangi oleh beberapa faktor seperti fakor pernikahan, globalisasi, kebersamaan, dan lainnya. Integrasi budaya salah satu upaya yang dilakukan untuk mengantisipasi terjadinya konflik atau meredam potensi konflik. Integrasi budaya merupakan wujud saling menghargai 
budaya satu dengan lainnya. Terjadinya integrasi budaya tidak berarti menghilangkan budaya aslinya atau meleburkan identitas budaya. Integrasi budaya adalah tindakan sportif yang ditunjukkan berupa dukungan. Integrasi budaya dapat membantu dalam pengelolaan keragaman budaya di Lampung.

Hadirnya integrasi budaya mendorong rasa kebinekaan budaya yakni meskipun berbedabeda suku, akan tetapi dipersatukan dalam satu tubuh yaitu sebagai masyarakat Lampung. Sisi buruk dari integrasi budaya adalah kaburnya budaya bagi generasi penerus. Menurut Samovar iintegrasi budaya dapat membuat kabur identitas budaya baru (Samovar, 2010: 200). Anak muda Lampung menyebutnya sebagai identitas budaya modern, artinya penyesuaian budaya dari orangtua dengan situasi dan kondisi saat ini. Berdasarkan pengamatan di lapangan, identitas budaya baru dipraktikkan melalui bahasa yang digunakan dalam aktivitas komunikasi sehari-hari. Orangtua maupun anak sudah jarang menggunakan bahasa daerah Lampung, akan tetapi bahasa yang dipilih adalah bahasa Indonesia. Mereka berpendapat bahwa bahasa tersebut lebih menunjukkan rasa kebinekaan, menghargai satu budaya dengan budaya lain yang mengalami integrasi budaya setelah orang tuanya menikah.

Dampak lain dari pernikahan berbeda budaya yakni sulitnya anak menentukan identitas sosial. Ketika anak berada di dalam kelompok masyarakat tentu ia merasa bingung untuk menyatakan "siapa saya" dan dari mana "asal usul saya". Hal ini yang menjadi bagian dari pekerjaan rumah sekaligus tanggung jawab orangtua dan lingkungan sekitar. Samovar menjelaskan bahwa menentukan identitas sosial seringkali lebih sulit ketika terjadinya integrasi budaya (2010: 186). Selain karena adanya pernikahan antarbudaya juga globalisasi. Terpaan media massa maupun media sosial saat ini sangat berkontribusi besar terhadap pola pikir seseorang. Budaya populer yang saat ini digandrungi oleh para remaja memiliki andil terhadap pembentukan identitas sosial. Mereka lebih bangga menyebutkan makanan cepat saji ketimbang makanan tradisional; Sangat percaya diri dengan mengenakan pakaian modern dibandingkan dengan pakaian batik khas daerah.

Adanya pernikahan antarbudaya maupun arus globalisasi yang terus merongrong generasi milenia, maka peran orangtua dan lingkungan sekitar sangat dibutuhkan. Mendidik dan mengenalkan nilai-nilai lokal di tengah masyarakat multikultural sangat diperlukan. Misalnya, orangtua membiasakan komunikasi dengan menggunakan bahasa ibunya. Seringkali bahasa daerah diabaikan. Mereka lebih memilih menggunakan Bahasa Indonesia atau bahasa asing. Padahal bahasa ibu merupakan bahasa pokok sebelum mempelajari bahasa lainnya. Mengenali bahasa sendiri lebih sebelum bahasa orang lain merupakan salah satu kompetensi yang harus dimiliki dalam komunikasi antarbudaya.

Jandt menjelaskan bahwa mengetahui dan mempelajari budaya sendiri sebelum budaya orang lain dapat mempermudah terjadinya negosiasi budaya (2013: 36). Memahami budaya orang lain merupakan keahlian yang harus dimiliki oleh setiap individu. Selain itu, komunikasi antarbudaya juga menuntut kekuatan personal dalam hal memahami budayanya. Hal ini sebagai upaya untuk mempertahankan budaya di hadapan orang lain. Stella Ting Tomey merujuk pada Face Negotation Theory untuk menjelaskan konflik budaya (dalam Griffin, 2011: 407). Menurut teori ini setiap individu tidak menginginkan kehilangan muka sehingga ia berusaha untuk menampilkan muka terbaiknya di hadapan publik. Hal itu dilakukan melalui usaha negosiasi dengan publik. Berusaha meyakinkan dan mengambil dukungan dari publik bahwa tidak ada yang buruk dari budayanya. Apapun yang ditampilkan untuk menunjukkan kepada publik bahwa apa yang dipikirkan tentang sesuatu hal itu tidak benar dan yang benar adalah sesuai dengan yang ditampilkan oleh dirinya. Individu menjadi representasi bagi kelompok tertentu ketika proses negosiasi muka ini dilakukan.

Integrasi budaya di Lampung terlepas dapat mendorong lahirnya budaya baru bagi generasi milenium atau membuat kabur budaya, akan tetapi hasil penelitian ini menemukan bahwa integrasi budaya sangat membantu dalam pengelolaan keragaman budaya. Upaya yang terus dilakukan di tengah masyarakat majemuk untuk membangun kebinekaan yaitu rasa menjadi satu bagian di dalam keragaman budaya. Satu bagian dari masyarakat "Lampung Sai" atau Lampung satu dan bagian dari Bangsa Indonesia. Pesan komunikasi pada media atribut Siger juga merepresentasikan tentang tanggung jawab masyarakat Lampung terhadap 
integrasi budaya. Mereka dituntut untuk berperilaku sesuai dengan nilai-nilai gelar yang disandang. Setiap gelar menekankan pada nilai kebersamaan, gotong royong, keterbukaan, kasih sayang, saling menghormati, dan saling mendukung. Gelar yang direpresentasikan pada setiap lekukan atribut Siger membuktikan bahwa sejak awal suku Lampung sudah siap untuk hidup berdampingan dengan suku lainnya.

Simbol Lampung seperti atribut Siger dan tagline "Sai Bumi Khua Jukhai" merupakan langkah awal Ulun Lampung dan pemerintah daerah setempat untuk memelihara reputasi. Memasukan philosofi Juluk Adok atau gelar ke dalam simbol fisik atribut Siger merupakan langkah kehati-hatian atau antisipasi leluhur dalam menjaga nilai lokal Lampung. Nilainilai yang sejak lama dibangun untuk menjaga reputasi tentang Lampung. Reputasi secara konsep dibangun oleh faktor kredibilitas, kepercayaan, keandalan, dan tanggung jawab (Ardianto, 2013: 69).

Kredibilitas dapat diartikan sebagai kemampuan suku Lampung dalam mengelola keragaman budaya. Jandt menjelaskan kemampuan komunikasi antarbudaya diawali dari usaha untuk memahami budaya diri sendiri dan budaya orang lain (2013: 36). Pemahaman terhadap budaya sendiri dapat mendorong kepercayaan orang lain. Diantaranya tentang nilai-nilai di dalam atribut Siger yang menekankan pada kebersamaan.

Kepercayaan sebagai wujud keterbukaan dan sikap ramah masyarakat Lampung sehingga membuat suku pendatang merasa aman, dan nyaman tinggal di Lampung. Keandalan artinya bahwa kesungguhan atas itikad Ulun Lampung harus dibuktikan dengan tindakan nyata bahwa mereka dapat hidup berdampingan dengan suku lainnya. Faktor tanggung jawab mempengaruhi reputasi karena pengelolaan keragaman budaya bukan tanggung jawab perorangan, pemerintah atau kelompok saja, akan tetapi mengelola ragam budaya merupakan tanggung jawab bersama. Ulun Lampung sangat menjunjung tinggi nilai gotong royong atau Sakai Sambayan.

Pengelolaan reputasi masyarakat Lampung dalam mewujudkan kebinekaan didukung oleh bukti-bukti sejarah. Salah satu sejarah yang diwariskan adalah pesan dan nilai-nilai yang terkandung di dalam simbol fisik atribut Siger. Terdapat pesan utama atau message platform bahwa Ulun Lampung menjunjung tinggi keberagaman dan menerima keberagaman. Pesan tersebut selalu ditanamkan melalui philosofi Siger. Pemahaman setiap individu terhadap philosofi Siger dapat dijadikan sebagai bahan melindungi, dan mempertahankan budayanya.

Stella Ting Tomey dalam Griffin memperkenalkan face negotiation theory dalam mengkaji konflik budaya dengan menggunakan negosiasi muka (Griffin, 2011: 407). Teori ini memiliki asumsi bahwa setiap individu atau kelompok tidak ingin kehilangan muka. Mereka berupaya untuk menggali informasi agar dapat mempertahankan muka dihadapan publik. Pertahanan tersebut dilakukan melalui negosiasi. Diharapkan dengan negosiasi dapat mempertahankan atau memulihkan reputasi. Demikian halnya dengan message platform yang terkandung di dalam atribut Siger. Siger diperkenalkan secara organik agar masyarakat Lampung mengetahui, dan bertanggung jawab untuk mempertahankan nilai yang terdapat pada atribut Siger.

Pesan komunikasi tentang nilai lokal di dalam setiap lekukan Siger merupakan bagian dari strategi aksi dan komunikasi Ulun Lampung dalam mengenalkan nilai-nilai budaya. Pesan tersebut senantiasa dikelola melalui negosiasi yang dilakukan oleh setiap masyarakat Lampung. Lahirnya keberagaman budaya di Lampung menjadi bukti bahwa upaya menjaga reputasi Lampung saat ini dilakukan secara bersama. Tidak hanya menjadi tanggung jawab Ulun Lampung, akan tetapi menjadi kewajiban bagi suku-suku lainnya yang berdomisili di Lampung yang telah berikrar menjadi Ulun Lampung atau Lampung Sai dan Sai Bumi Khua Jukhai, artinya menjadi orang Lampung, Lampung satu tidak ada suku pribumi dan nonpribumi, akan tetapi yang ada Lampung Sai untuk bersama-sama menjaga reputasi Lampung.

\section{SIMPULAN}

Bentuk setiap lekukan di dalam atribut Siger menggambarkan philosofi terhadap falsafah hidup masyarakat Lampung. Falsafah tentang Juluk Adok atau pemberian gelar yang bertujuan bahwa setiap individu harus berperilaku sesuai dengan gelar yang disandangnya. Juluk Adok mengandung nilai bahwa masyarakat Lampung menjunjung tinggi rasa kebersamaan, gotong 
royong, ramah, dan terbuka. Lekukan pada Siger merepresentasikan tujuh tingkatan gelar di dalam adat Saibatin Lampung. Siger juga menggambarkan sembilan lekukan atau sembilan marga atau Siwo Megou dalam adat Pepadun Lampung.

Keragaman budaya di Lampung melahirkan identitas budaya baru. Hal ini menjadi aspek positif karena dapat membantu terjadinya integrasi budaya. Hadirnya budaya baru juga bagian dari proses pengelolaan keragaman budaya. Budaya baru mendorong setiap generasi untuk mempelajari budaya lain terutama budaya berbeda dari orang tuanya. Integrasi budaya juga dapat melawan masuknya sisi gelap dari identitas budaya seperti perilaku etnosentrisme, rasisme, steorotif, dan prasangka. Keberhasilan dalam mengelola keragaman selain melahirkan budaya baru juga dapat menjadi pondasi dalam membangun kebinekaan budaya. Perbedaan budaya yang disikapi sebagai bagian dari satu tubuh yakni masyarakat Lampung Sai atau Lampung Satu bersama-sama membangun dan mempertahankan Lampung sebagai wilayah multikultur.

Pernyataan terakhir sebagai saran dari tulisan ini bahwa pentingnya peran orangtua dan lingkungan sekitar untuk mengawal setiap integrasi budaya. Tidak ada yang buruk dari proses integrasi budaya selama adanya pemahaman dari orangtua kepada anak-anaknya. Justru integrasi budaya dapat membuat anak lebih kaya akan budaya. Integrasi budaya juga dapat membantu proses pengelolaan keragaman budaya di dalam masyarakat multikultur. Diperlukan pula peran pemerintah daerah setempat untuk memberikan edukasi budaya lokal disetiap pembelajaran sekolah melalui kurikulum yang ramah budaya.

\section{DAFTAR PUSTAKA}

Ardianto, E. (2013). Hand book of public relations. Bandung: Simbiosa Rekatama Media.
Aryanti, N. Y. (2014). Pengembangan identitas remaja transmigran jawa di lampung melalui pertemanan antar budaya di sekolah. Jurnal Kajian Komunikasi. Fakultas Ilmu Komunikasi Universitas Padjadjaran. Volume 2 Nomor 1. Hlm. 93-104.

Creswell, J. (2014). Penelitian kualitatif dan desain riset. Memilih di antara lima pendekatan. Edisi ketiga. Yogyakarta: Pustaka Pelajar.

Griffin, E. M. (2011). A first look at communication theories. Eighth Edition. USA: MC Graw Hill.

Heryadi, H. \& Silvana, H. (2013). Komunikasi antarbudaya dalam masyarakat multikultur. Jurnal Kajian Komunikasi. Universitas Padjadjaran. Volume 1 Nomor 1. Hlm. 95108.

Hidayat, D. (2014). Representasi nemui-nyimah sebagai nilai-nilai kearifaan lokal. Jurnal Ilmu Komunikasi. Universitas Riau. Volume 5 nomor 1.

(2014). Social and cultural identity pendekatan face negotation theory dan public relations multikulturalisme negara JermanChina dan Indonesia. Jurnal Komunikasi Asosiasi Pendidikan Tinggi Ilmu Komunikasi. (ASPIKOM). Volume 2 Nomor 2. Hlm. 115126.

Jandt, E. F. (2013). An introduction to intercultural communication: identities in a global community. USA California: Sage.

Prayudi. (2012). Public relations stratejik. Jogjakarta: UNP Press

Samovar, P. M. (2010). Komunikasi lintas budaya: communication between cultures. Jakarta: Salemba Humanika.

Smith, B. L. (2007). Engaging public relations. USA: Hunt Publishing Company.

Sujadi. (2013). Lampung sai bumi ruwa jurai. Jakarta: Cita Insan Madani.

Tench, Y. (2006). Exploring public relations. England: Pearson Education Limited.

Theaker, A. (2004). The public relations hand book. London: Routledge 